\title{
Anthraquinone-based demultiplexer and other multiple operations at the molecular level
}

\author{
NAVNEET KAUR ${ }^{\mathrm{a}, *}$ and SUBODH KUMAR ${ }^{\mathrm{b}}$ \\ ${ }^{a}$ Department of Chemistry, Panjab University, Chandigarh 160 014, India \\ ${ }^{b}$ Department of Chemistry, Guru Nanak Dev University, Amritsar 143 005, India \\ e-mail: neet_chem@yahoo.co.in
}

MS received 17 June 2013; revised 2 September 2013; accepted 22 October 2013

\begin{abstract}
Anthraquinone-based chemosensor $\mathbf{L}$ with pyridine units as additional functional groups has been found to show $\mathrm{pH}$-dependent multiple coordination modes towards different metal ions $\left(\mathrm{Co}^{2+}, \mathrm{Ni}^{2+}\right.$ and $\left.\mathrm{Cu}^{2+}\right)$. Based on these different absorption changes, this differential colorimetric chemosensor $\mathbf{L}$ has found promising applications as a multiple-mode molecular logic system, i.e., OR, three - input NOR, three - input INHIBIT, TRANSFER and 1:2 DEMUX.
\end{abstract}

Keywords. Anthraquinone; chemosensors; molecular logic gates; demultiplexer.

\section{Introduction}

The chemical structure of small tailormade molecular scaffolds that can transform macroscopic properties with respect to external inputs have recently gained great importance to sustain the development of information science and new technologies. ${ }^{1}$ Molecular logic gates or switches whose output (0 or 1$)$ depends on the input conditions, play pivotal roles in molecular computation. $^{2}$ The possibility of mimicking the function of silicon chips and building electronic devices using organic/inorganic molecules, based on their spectral responses toward an external stimulus, has been much explored. ${ }^{3}$

A number of molecular-level machines, elementary electronic devices, fluorescent logic gates (AND, OR, INHIBIT, etc.) and arranged logic circuits incorporating single logic gates have been established recently. ${ }^{4}$ Many different external physical signals, including optical, ${ }^{5}$ electrochemical potential, ${ }^{6}$ magnetic and sometime, ${ }^{7}$ by chemical signals such as $\mathrm{pH}$ changes or metal cations additions were applied to activate chemical processes mimicking computational operations. ${ }^{8} 9$ Mostly, chemical computing systems produce chemical output signals and these signals should be used as inputs for the next chemical computing operation when the individual chemical steps are connected in a complex chemical information processing network. In multifunctional systems, assembling of chemical computing units resulted in chemical devices performing basic
Boolean operations such as NOR, XOR, XNOR, INH and the most common combinational circuits, i.e., half- and full-adders and -subtractors, multiplexer, demultiplexer. ${ }^{10-18}$

An important function in information technology is signal multiplexing/demultiplexing. A 2:1 multiplexer (MUX) is a circuit with two data inputs, one address input and one output. The MUX selects the binary state from one of the data inputs and directs it to the output; the selected input depends on the binary state of the address input. Conversely, a 1:2 demultiplexer (DEMUX) is a circuit that possesses one data input, one address input and two outputs. The DEMUX routes the data input to one of the output lines, and the selected output is determined by the binary state of the address input. Hence, a multiplexer allows the encoding of multiple data streams into a single data line for transmission, and a demultiplexer can decode entangled data streams from a single signal. Molecules that can mimic the function of a 2:1 multiplexer or a 1:2 demultiplexer have recently been reported. ${ }^{19-21}$ However, these systems either rely on carefully designed multicomponent species and coupling to an external optical device ${ }^{20}$ or imply a dependence of the data input on the binary state of the address input. ${ }^{19-21}$ Demultiplexers based on solid-state nanostructures have also been described. ${ }^{22}$

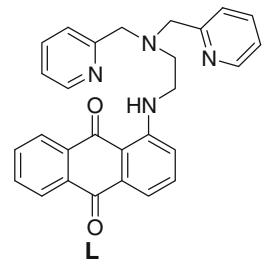

*For correspondence 
In continuation with our earlier report anthraquinone-based molecular logic systems, ${ }^{23}$ in this paper, we have shown that cation-induced modulations of the chemosensor's (L) absorption spectrum involve the appearance or disappearance of various bands in the visible region as well as different colour changes at different $\mathrm{pH}$ values. These different optical output signals (i.e., absorbance) can be used for construction of various molecular logic devices. More importantly, switching of the absorption properties at different $\mathrm{pH}$ values can form the basis for unimolecular 1:2 demultiplexer.

\section{Experimental}

A synthetic procedure for $\mathbf{L}$ and its detailed photophysical studies has already been reported. ${ }^{24}$

\section{Results and discussion}

\subsection{Metal ions switch}

In $\mathrm{CH}_{3} \mathrm{OH}: \mathrm{H}_{2} \mathrm{O}$ (4:1), the absorption spectrum of $\mathbf{L}$ showed a band with $\lambda_{\max }$ at $510 \mathrm{~nm}$. Addition of solutions of $\mathrm{Co}^{2+}, \mathrm{Ni}^{2+}$ and $\mathrm{Cu}^{2+}$ showed a visible colour change from red to blue and their UV-vis spectra exhibited differently red-shifted $(630-650 \mathrm{~nm})$ absorption bands (figure 1).

However, on lowering the $\mathrm{pH}$ to 4.0 , the solution of $\mathbf{L}$, with addition of $\mathrm{Co}^{2+}, \mathrm{Ni}^{2+}$ and $\mathrm{Cu}^{2+}$ gave respective blue $\left(\lambda_{\max } 620 \mathrm{~nm}\right)$, yellowish pink $\left(\lambda_{\max } 380,460\right.$ and $510 \mathrm{~nm}$ ) and yellow ( $\lambda_{\max } 460 \mathrm{~nm}$ ) colours (figure 2 ). Spectral fitting of the titration data of $\mathbf{L}$ against $\mathrm{Co}^{2+}$, $\mathrm{Ni}^{2+}$ and $\mathrm{Cu}^{2+}$ showed the formation of $1: 1$ complexes with $\log \beta$ values of $6.8 \pm 0.3,5.9 \pm 0.3$, and $7.10 \pm$ 0.72 , respectively. ${ }^{24}$

At $\mathrm{pH} 7.0$, the red shift in the case of $\mathrm{Co}^{2+}, \mathrm{Ni}^{2+}$ and $\mathrm{Cu}^{2+}$ points to aryl $\mathrm{NH}$ deprotonation. However, under acidic conditions, i.e., at $\mathrm{pH} 4.0$, the blue shift in the case of $\mathrm{Ni}^{2+}$ and $\mathrm{Cu}^{2+}$ and red shift in $\mathrm{Co}^{2+}$ shows differential mode of interaction of these metal ions towards sensor $\mathbf{L}$. Here, aryl NH coordinates with $\mathrm{Ni}^{2+}$ and $\mathrm{Cu}^{2+}$ to cause hypsochromic shift, however, $\mathrm{Co}^{2+}$ coordination along with deprotonation results in increased electron-density and red shift of spectral band.

This $\mathrm{pH}$-controlled switching between neutral and protonated forms of $\mathbf{L}$ was fully reversible and could be repeated many times with the same solution without any appreciable reduction in intensity in the absorption spectra. This particular spectroscopic behaviour and the chemical reversibility of the pH-switching can be used to obtain OR, NOR, INH, TRANSFER and 1:2 DEMUX functions.

\subsection{OR and NOR logic gates based on system}

L at $\mathrm{pH} 7.0$

The output of OR gate is normally switched on if either one or both inputs are turned on. As a consequence of observed absorbance of $\mathbf{L}(50 \mu \mathrm{M})$ at $\mathrm{pH} 7.0$ in the presence of $\mathrm{Cu}^{2+}$ and $\mathrm{Ni}^{2+}$, an OR gate can be easily applied by using $\mathrm{Cu}^{2+}(50 \mu \mathrm{M})$ and $\mathrm{Ni}^{2+}(50 \mu \mathrm{M})$ as two chemical inputs and absorbance at $620 \mathrm{~nm}$ as an output. In the absence of any of these cations, the absorbance at $620 \mathrm{~nm}$ of system $\mathbf{L}$ is relatively low $(<0.01$, output $0)$, whereas absorbance values are high $(>0.1$, output 1) in the presence of each or both of the two input. As a result, a two input OR logic gate is obtained according to the truth table in figure 3 .

NOR gates (and also NAND gates) are of potential interest because they are considered as universal gates which enable the combinatorial creation of all other basic Boolean operations. In the present system $\mathbf{L}$ $(50 \mu \mathrm{M})$, a three input NOR logic expression is yielded using absorbance output at $502 \mathrm{~nm}$ and 1 equiv. of $\mathrm{Co}^{2+}$, $\mathrm{Ni}^{2+}$ and $\mathrm{Cu}^{2+}$ as the inputs. As seen in figure 4, there is relatively high absorbance at $502 \mathrm{~nm}(>0.30$, output 1) when no ions are added. However, when one or both or all of the three inputs are operated, the absorbance of $\mathbf{L}$ is decreased $(<0.2$, output 0$)$. This process can

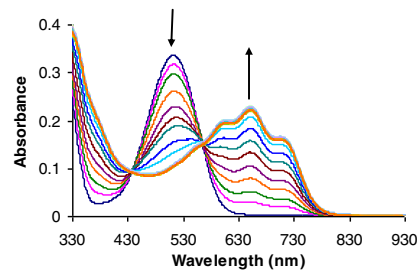

(a)

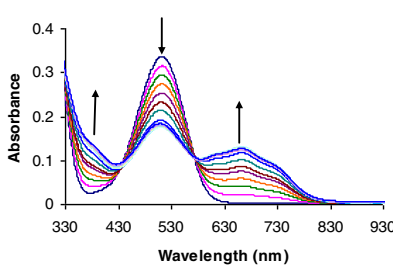

(b)

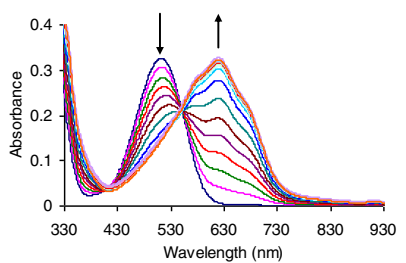

(c)

Figure 1. UV-vis spectra of $\mathbf{L}\left(50 \mu \mathrm{M} ; \mathrm{CH}_{3} \mathrm{OH}: \mathrm{H}_{2} \mathrm{O} 4: 1 ; \mathrm{pH} 7.0 \pm 0.1\right)$ upon addition of different concentrations of (a) $\mathrm{Co}^{2+} ;(\mathbf{b}) \mathrm{Ni}^{2+}$ and (c) $\mathrm{Cu}^{2+}$. 


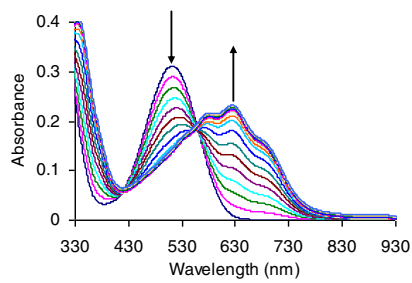

(a)

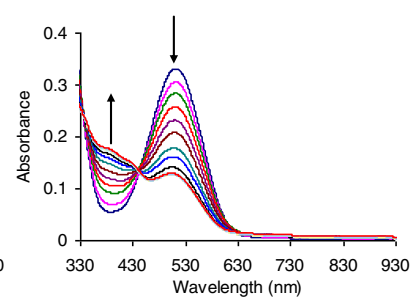

(b)

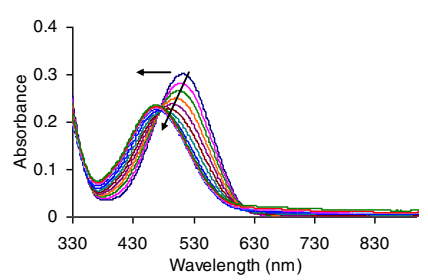

(c)

Figure 2. Response of absorption spectrum of $\mathbf{L}(50 \mu \mathrm{M})\left(\mathrm{H}_{2} \mathrm{O}\right.$, acetic acid-sodium acetate, $\mathrm{pH} 4.0 \pm 0.1)$ towards different concentrations of $(\mathbf{a}) \mathrm{Co}^{2+} ;(\mathbf{b}) \mathrm{Ni}^{2+}$ and $(\mathbf{c}) \mathrm{Cu}^{2+}$.
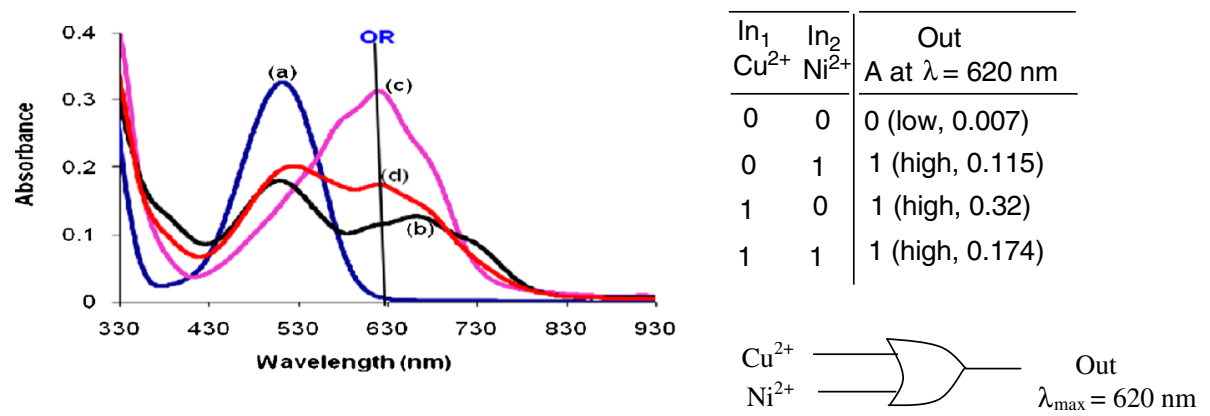

Figure 3. UV-vis spectra of $\mathbf{L}\left(50 \mu \mathrm{M} ; \mathrm{CH}_{3} \mathrm{OH}: \mathrm{H}_{2} \mathrm{O} 4: 1 ; \mathrm{pH} 7.0 \pm 0.1\right)$ under different input conditions ((a) blank; (b) $\mathbf{L}+\mathrm{Ni}^{2+}$; (c) $\mathbf{L}+\mathrm{Cu}^{2+}$ and (d) $\mathbf{L}+\mathrm{Ni}^{2+}+$ $\left.\mathrm{Cu}^{2+}\right)$, the truth table and the OR logic scheme.

be referred to as a NOR logic system which integrates a NOT and an OR logic gate. Thus, the multiplicity of logic operations is also demonstrated for a three input photonic system. It should be noted that three inputs can provide much more information and show interesting behaviour at the molecular level such as the consequence of chemical congregations.

\subsection{TRANSFER and INHIBIT logic gates based on system $\mathbf{L}$ at $\mathrm{pH} 4.0$}

The hypsochromic shift observed in case of system $\mathbf{L}$ on addition of $\mathrm{Cu}^{2+}$ brings another advantage. Shifting of observable wavelength from $\lambda 620 \mathrm{~nm}(\mathrm{pH} 7.0)$ to $\lambda$ $410 \mathrm{~nm}(\mathrm{pH} 4.0)$ in this case results in 'TRANSFER' $14 e$

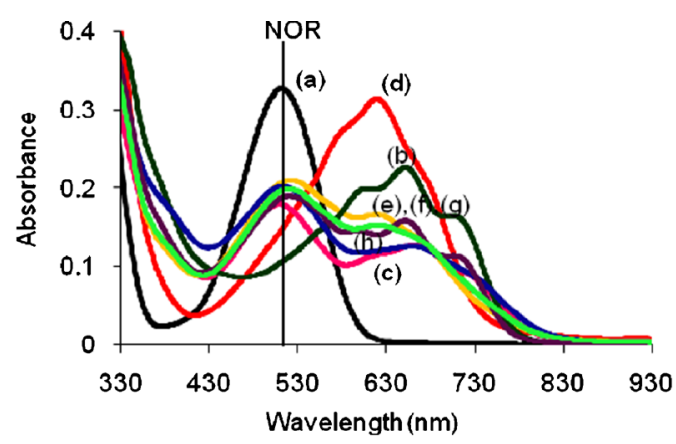

\begin{tabular}{|c|c|c|c|}
\hline $\begin{array}{l}\ln _{1} \\
\mathrm{Cu}^{2+}\end{array}$ & $\begin{array}{l}\mathrm{In}_{2} \\
\mathrm{Ni}^{2+}\end{array}$ & $\begin{array}{l}\ln _{3} \\
\mathrm{Co}^{2+}\end{array}$ & $\begin{array}{c}\text { Out } \\
\text { A at } \lambda=502 \mathrm{~nm}\end{array}$ \\
\hline 0 & 0 & 0 & 1 (high, 0.32) \\
\hline 0 & 0 & 1 & 0 (low, 0.09) \\
\hline 0 & 1 & 0 & 0 (low, 0.179) \\
\hline 1 & 0 & 0 & 0 (low, 0.132) \\
\hline 0 & 1 & 1 & 0 (low, 0.180) \\
\hline 1 & 0 & 1 & 0 (low, 0.188) \\
\hline 1 & 1 & 0 & 0 (low, 0.175) \\
\hline 1 & 1 & 1 & 0 (low, 0.20) \\
\hline
\end{tabular}

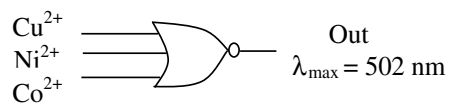

Figure 4. UV-vis spectra of $\mathbf{L}\left(50 \mu \mathrm{M} ; \mathrm{CH}_{3} \mathrm{OH}: \mathrm{H}_{2} \mathrm{O} 4: 1 ; \mathrm{pH} 7.0 \pm 0.1\right)$ under different input conditions ((a) blank; (b) $\mathbf{L}+\mathrm{Co}^{2+}$; (c) $\mathbf{L}+\mathrm{Ni}^{2+}$; (d) $\mathbf{L}+\mathrm{Cu}^{2+}$; (e) $\mathbf{L}+$ $\mathrm{Ni}^{2+}+\mathrm{Co}^{2+} ;$ (f) $\mathbf{L}+\mathrm{Cu}^{2+}+\mathrm{Co}^{2+} ;\left(\right.$ g) $\mathbf{L}+\mathrm{Cu}^{2+}+\mathrm{Ni}^{2+}$ and (h) $\left.\mathbf{L}+\mathrm{Cu}^{2+}+\mathrm{Ni}^{2+}+\mathrm{Co}^{2+}\right)$, the truth table and the NOR logic scheme. 


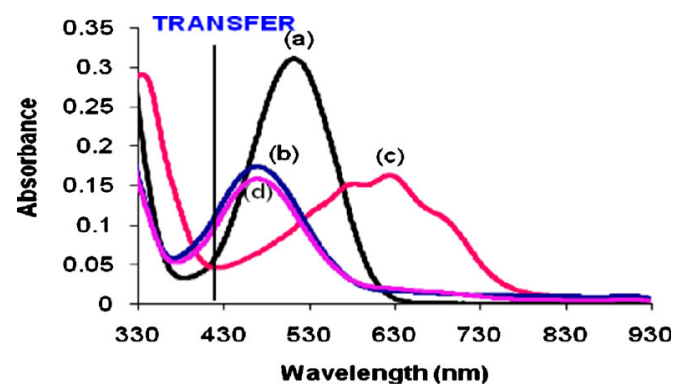

\begin{tabular}{|c|c|c|}
\hline $\begin{array}{l}\mathrm{In}_{1} \\
\mathrm{Cu}^{2+}\end{array}$ & $\begin{array}{l}\mathrm{In}_{2} \\
\mathrm{Co}^{+}\end{array}$ & $\begin{array}{l}\text { Out } \\
\text { A at } \lambda=410 \mathrm{~nm}\end{array}$ \\
\hline 0 & 0 & 0 (low, 0.045) \\
\hline 1 & 0 & 1 (high, 0.101) \\
\hline 0 & 1 & 0 (low, 0.05) \\
\hline 1 & 1 & 1 (high, 0.092) \\
\hline
\end{tabular}

Figure 5. UV-vis spectra of $\mathbf{L}(50 \mu \mathrm{M} ; \mathrm{pH} 4.0 \pm 0.1)$ under different input conditions ((a) blank; (b) $\mathbf{L}+\mathrm{Cu}^{2+}$; (c) $\mathbf{L}+\mathrm{Co}^{2+}$ and (d) $\mathbf{L}+\mathrm{Cu}^{2+}+\mathrm{Co}^{2+}$ ) and the truth table.

logic. TRANSFER logic requires that the signal is 0 when both inputs are 0 and when one of the two inputs is 1 . However, when the other input is 1 or when both are 1 , the output is 1 . The free $\mathbf{L}(50 \mu \mathrm{M})(\mathrm{A} 0.045)$ and addition of $\mathrm{Co}^{2+}$ (pH 4.0) (A 0.05) leads to low output at $410 \mathrm{~nm}$. It is only in the presence of $\mathrm{Cu}^{2+}$, the output is high (A 0.101, output 1) and remains high even after addition of both $\mathrm{Cu}^{2+}(50 \mu \mathrm{M})$ and $\mathrm{Co}^{2+}(\mathrm{A} 0.092)$ (figure 5).

INHIBIT logic deserves some attention because it demonstrates a non-commutative behaviour, that is, one of the inputs can disable the whole system. Using the metal ions, $\mathrm{Ni}^{2+}, \mathrm{Cu}^{2+}$ and $\mathrm{Co}^{2+}$, an integrated logic circuit is constructed in system $\mathbf{L}(50 \mu \mathrm{M}, \mathrm{pH} 4.0)$ (figure 6). Only in the presence of $\mathrm{Co}^{2+}$ (1 equiv.), output at $620 \mathrm{~nm}$ is 1 ( $>0.20$, output 1$)$. In the presence of 1 equiv. of $\mathrm{Cu}^{2+}$ or $\mathrm{Ni}^{2+}$ or both of them, the resultant outputs are all $0(<0.04$, output 0$)$. This is a combinational logic circuit incorporating an OR and an INHIBIT logic gates where the output of OR gate serves as input for INHIBIT gate.

\subsection{1:2 Demultiplexer in $\mathrm{CH}_{3} \mathrm{OH}: \mathrm{H}_{2} \mathrm{O}(4: 1)$}

The system can be easily reconfigured to behave as a 1:2 demultiplexer by changing the optical input and output channels. The Boolean algebraic expression for a two output DeMUX switch is In\#a(Out $\left.{ }_{1}, \mathrm{Out}_{2}\right)$, the \# symbol denoting a demultiplexer function and ' $a$ ' is address input. This expression says that, if $a=0$, then the first argument $\left(\mathrm{Out}_{1}\right)$ equals In and the second argument $\left(\mathrm{Out}_{2}\right)$ is disabled; conversely, if $a=1, \mathrm{Out}_{2}$ is In and Out $_{1}$ is disabled. The variable preceding \# is the input variable and the symbol following \# is the control data variable. The variables in brackets are the output variables of the two output demultiplexer, which possesses one input $\left(\mathrm{In}=\mathrm{Cu}^{2+}\right)$, one address input $(a=\mathrm{pH})$ and two outputs $\left(\mathrm{Out}_{1}=620 \mathrm{~nm}\right.$ and $\left.\mathrm{Out}_{2}=401 \mathrm{~nm}\right)$.

The performance of chemosensor $\mathbf{L}$ as a molecular digital demultiplexer was assessed by using $\mathrm{CH}_{3} \mathrm{OH}: \mathrm{H}_{2} \mathrm{O}(4: 1)$ solution of $\mathbf{L}(50 \mu \mathrm{M})$ and measuring the absorbance values at the two output destinations (620 nm and $401 \mathrm{~nm}$ ) for the $\mathrm{Cu}^{2+}$ input at different

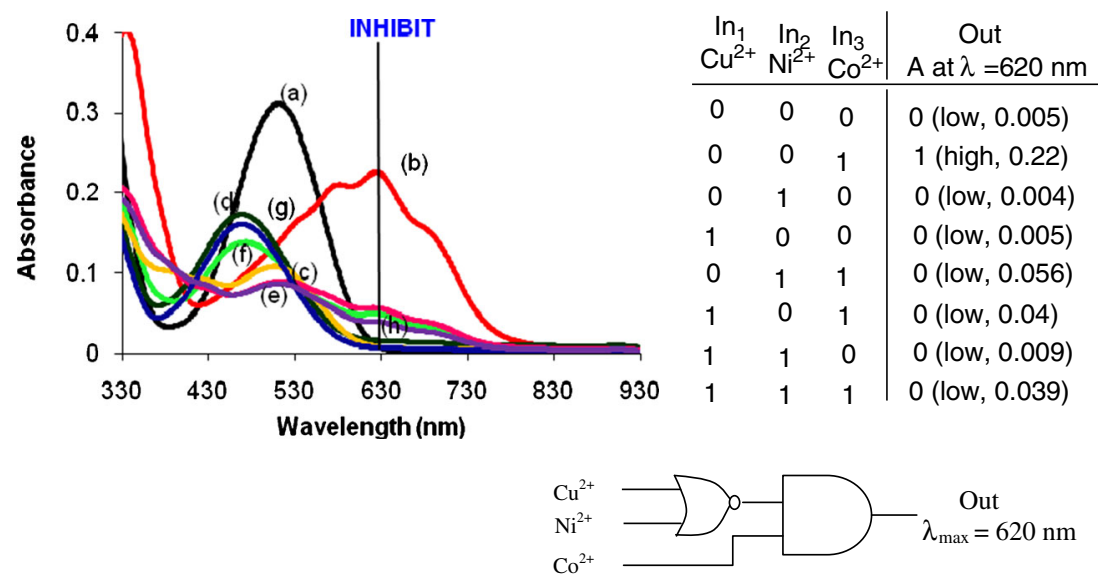

Figure 6. UV-vis spectra of $\mathbf{L}(50 \mu \mathrm{M} ; \mathrm{pH} 7.0 \pm 0.1)$ under different input conditions ((a) blank; (b) $\mathbf{L}+\mathrm{Co}^{2+}$; (c) $\mathbf{L}+\mathrm{Ni}^{2+}$; (d) $\mathbf{L}+\mathrm{Cu}^{2+}$; (e) $\mathbf{L}+\mathrm{Ni}^{2+}+\mathrm{Co}^{2+}$; (f) $\mathbf{L}+\mathrm{Cu}^{2+}+\mathrm{Co}^{2+} ;\left(\right.$ g) $\mathbf{L}+\mathrm{Cu}^{2+}+\mathrm{Ni}^{2+}$ and (h) $\mathbf{L}+$ $\left.\mathrm{Cu}^{2+}+\mathrm{Ni}^{2+}+\mathrm{Co}^{2+}\right)$, the truth table and the INHIBIT logic scheme. 


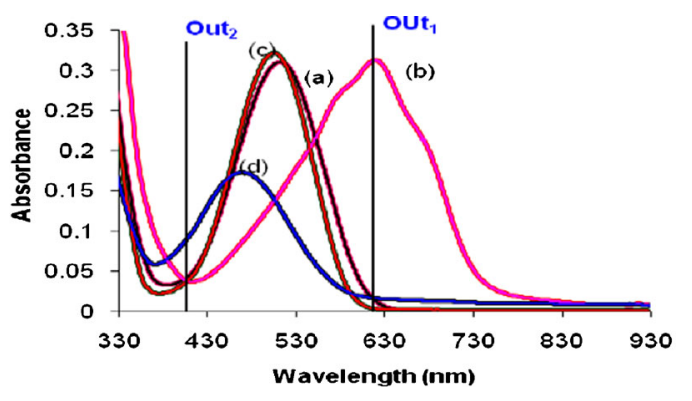

\begin{tabular}{c|c|c|c}
\hline $\begin{array}{l}\ln _{1} \\
\mathrm{Cu}^{2+}\end{array}$ & $\begin{array}{c}a \\
(\mathrm{pH})\end{array}$ & $\begin{array}{c}\mathrm{Out}_{1}(\mathrm{~A}) \\
\lambda=620 \mathrm{~nm}\end{array}$ & $\begin{array}{c}\mathrm{Out}_{2}(\mathrm{~A}) \\
\lambda=401 \mathrm{~nm}\end{array}$ \\
\hline 0 & 0 & 0 (low, 0.003) & 0 (low, 0.036) \\
1 & 0 & 1 (high, 0.32) & 0 (low, 0.037) \\
0 & 1 & 0 (low, 0.001) & 0 (low, 0.03) \\
1 & 1 & 0 (low, 0.012) & 1 (high, 0.083)
\end{tabular}

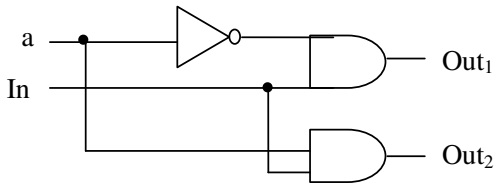

Figure 7. UV-vis spectra of $\mathbf{L}(50 \mu \mathrm{M})$ with $\mathrm{Cu}^{2+}$ as input having address input as $a$ $(\mathrm{pH}=7.0, a=0 ; \mathrm{pH}=4.0, a=1)$, the truth table and the DEMUX logic scheme.

$\mathrm{pH}$ values $(\mathrm{pH}=4.0$ and $\mathrm{pH}=7.0)$ (figure 7). If the address input is $0(\mathrm{pH}=7.0)$, the binary state of the data input is transmitted to Out $_{1}(620 \mathrm{~nm})$ and when the address input is $1(\mathrm{pH}=4.0)$, the binary data input is transmitted to $\mathrm{Out}_{2}(401 \mathrm{~nm})$.

\section{Conclusion}

We have found that chemosensor $\mathbf{L}$ can carry out logic operations with multiply configurable multiple outputs by selecting the initial states and chemical inputs. As a result, OR, three-input NOR, three-input INHIBIT and TRANSFER logic gates are achieved at the molecular level. Also, the $\mathrm{pH}$-driven modulations of absorption signals allows the implementation of 1:2 demultiplexer digital function.

\section{Acknowledgements}

We thank the Department of Science and Technology (DST), New Delhi for financial assistance.

\section{References}

1. (a) Feringa B L 2001 Molecular switches (New York: Wiley-VCH Express) p 37; (b) Irie M 2000 Chem. Rev. 100 1685; (c) Misra A, Srivastava P and Shahid M 2012 Analyst 1373470

2. (a) Moore G E 1965 Electronics 38 114; (b) Szacilowski K 2008 Chem. Rev. 108 3481; (c) Liu Y, Jiang W, Zhang H Y and Li C J 2006 J. Phys. Chem. B. 110 14231; (d) Katz E and Privman V 2010 Chem. Soc. Rev. 391835

3. (a) de Silva A P and McClenaghan N D 2002 Chem.Eur. J. 8 4935; (b) de Silva A P, Gunaratne H Q N and McCoy C P 1993 Nature 364 42; (c) Credi A 2007 Angew. Chem. Int. Ed. 46 5472; (d) Suresh M, Jose D A and Das A 2007 Org. Lett. 9 441; (e) Suresh M Ghosh A and Das A 2007 Tetrahedron Lett. 48 8205; (f) Andreasson J and Pischel U 2010 Chem. Soc. Rev. 39 174
4. (a) Raymo F M 2002 Adv. Mater. 14 401; (b) de Silva A P and McClenaghan N D 2004 Chem. Eur. J. 10 574; (c) Magri D C, Vance T P and de Silva A P 2007 Inorg. Chim. Acta 360 751; (d) Zhaoa X and Zhi Huang C 2010 Analyst 1352853

5. (a) Perez-Inestrosa E, Montenegro J M, Collado D, Suau R and Casado J 2007 J. Phys. Chem. C 111 6904; (b) Fang C J, Zhu Z, Sun W, Xu C H and Yan C H 2007 New J. Chem. 31 580; (c) Sadhu K K, Bag B and Bharadwaj P K 2007 J. PhotoChem. Photobiol. A185 231

6. (a) Zhou Y C, Wu H, Qu L, Zhang D Q and Zhu D B 2006 J. Phys. Chem. B110 15676; (b) Mendes P M, Flood A H and Stoddart J F 2005 Appl. Phys. A80 1197; (c) Hiratsuka M, Ikeda S, Aoki T and Higuchi T 2004 IEICE Trans. Electron E87C 1804

7. Vasilyev S, Pita M and Katz E 2008 Electroanalysis 20 22

8. (a) Credi A, Balzani V, Langford S J, Stoddart J F 1997 J. Am. Chem. Soc. 119 2679; (b) Wang Z X, Zheng G R and Lu P 2005 Org. Lett. 7 3669; (c) Nishimura G, Maehara H, Shiraishi Y and Hirai T 2008 Chem. Eur. J. 14259

9. (a) Privman V, Strack G, Solenov D, Pita M and Katz E 2008 J. Phys. Chem. B112 11777; (b) Privman M, Tam T K, Pita M and Katz E 2009 J. Am. Chem. Soc. 131 1314

10. Balzani V, Credi A and Venturi M 2008 Molecular devices and machines - Concepts and perspectives for the nanoworld, 2nd edition (Weinheim: Wiley-VCH) Chapter 9

11. (a) Jiang W, Jhang H and Liu Y 2009 Front. Chem. China 4 292; (b) Kou S Z, Lee H N, Van Noort D, Swamy K M K, Kim S H, Soh J H, Lee K M, Nam $\mathrm{S}$ W, Yoon J and Park S 2008 Angew. Chem. Int. Ed. 47 872; (c) Zhang L, Whitfield W A and Zhu L 2008 Chem. Commun. 1880; (d) Wagner N and Ashkenasy G 2009 Chem. Eur. J. 15 1765; (e) Raymo F M 2002 Adv. Mater. 14 401; (f) Balzani V, Credi A and Venturi M 2003 Chem. Phys. Chem. 4 49; (g) de Silva A P 2005 Nat. Mater. 4 15; (h) Gust D, Moore T A and Moore A L 2006 Chem. Commun. 1169

12. (a) Kumar S, Luxami V, Saini R and Kaur D 2009 Chem. Commun. 3044; (b) Bozdemir O A, Guliyev R, Buyukcakir O, Selcuk S, Kolemen S, Gulseren G, Nalbantoglu T, Boyaci H and Akkaya E U $2010 \mathrm{~J}$. Am. 
Chem. Soc. 132 8029; (c) Uchiyama S, McClean D D, Iwai K and de Silva A P 2005 J. Am. Chem. Soc. 127 8920; (d) de Silva A P, Leydet Y, Lincheneau C and McClenaghan N D 2006 J. Phys. Condens. Matter 18 S1847; (e) de Silva A P, de Silva S S K, Goonesekera N C W, Gunaratne H Q N, Lynch, P L M, Nesbitt K R, Patuwathavithana S T and Ramyalal N L D S 2007 J. Am. Chem. Soc. 1293050

13. (a) Sun W, Zhou C, Xu C, Fang C J, Zhang C, Li Z X and Yan C H 2008 Chem. Eur. J. 14 6342; (b) Suresh M, Gosh A and Das A 2008 Chem. Commun. 3906; (c) Andreasson J, Straight S D, Moore TA, Moore A L and Gust D 2009 Chem. Eur. J. 15 3936; (d) Margulies D, Melman G and Shanzer A 2005 Nat. Mater. 4 768; (e) Margulies D, Melman G and Shanzer A 2006 J. Am. Chem. Soc. 128 4865; (f) Margulies D, Felder C E, Melman G and Shanzer A 2007 J. Am. Chem. Soc. 129 347; (g) Szaciłowski K 2004 Chem. Eur. J. 10 2520; (h) Sortino S, Petralia S, Di Bella S, Tomasulo M and Raymo F M 2006 New J. Chem. 30 515

14. (a) Kumar M, Dhir A and Bhalla V 2009 Org. Lett. 11 2567; (b) Remacle F, Levine R D 2006 Phys. Rev. A73 033820; (c) Remacle F, Speiser S and Levine R D 2001 J. Phys. Chem. B105 5589; (d) Remacle F, Weinkauf R and Levine R D 2006 J. Phys. Chem. A110 177; (e) Baytekin H T and Akkaya E U 2000 Org. Lett. 2 1725; (f) Andreasson J, Straight S D, Moore T A, Moore A L and Gust D 2008 J. Am. Chem. Soc. 130 11122; (g) Coskun A, Deniz E and Akkaya E U 2005 Org. Lett. 7 5187

15. (a) Baron R, Lioubashevski O, Katz E, Niazov $\mathrm{T}$ and Willner I 2006 Angew. Chem. Int. Ed. 45 1572; (b) Pita M and Katz E 2008 J. Am. Chem. Soc. 130 36; (c) Rurack K, Trieflinger C, Koval chuck A and Daub J 2007 Chem. Eur. J. 13 8998; (d) Strack G, Ornatska M, Pita M and Katz E 2008 J. Am. Chem. Soc. 1304234

16. (a) Tian H 2010 Angew. Chem. Int. Ed. 49 4710; (b) Qu D H, Wang Q C and Tian H 2005 Angew. Chem. Int. Ed.
44 5296; (c) Guo Z Q, Zhu W H, Shen L J and Tian H 2007 Angew. Chem. Int. Ed. 46 5549; (d) Guo Z Q, Zhao P, Zhu W H, Huang X M, Xie Y S and Tian H $2008 \mathrm{~J}$. Phys. Chem. C 112 7047; (e) Tian H and Feng L 2008 J. Mater. Chem. 18 1617; (f) Stojanovic M N, Semova S, Kolpashchikov D, Macdonald J and Stefanovic D C 2005 J. Am. Chem. Soc. 127 6914; (g) Macdonald J, Li Y, Sutovic M, Lederman H, Pendri K, Lu W, Andrews B L, Stefanovic D and Stojanovic M N 2006 Nano Lett. 6 2598

17. (a) de Ruiter G, Tartakovsky E, Oded N, Van der Boom M E 2010 Angew. Chem. Int. Ed. 49 169; (b) Pischel U and Andreasson J 2010 New J. Chem. 34 2701; (c) Seelig G, Soloveichnik D, Zhang D Y and Winfree E 2006 Science 314 1585; (d) Zhang D Y, Turberfield A J, Yurke B and Winfree E 2007 Science 318 1121; (e) Ashkenasy G and Ghadiri M R 2004 J. Am. Chem. Soc. 126 11140; (f) Gianneschi N C and Ghadiri M R 2007 Angew. Chem. Int. Ed. 46 3955; (g) Voelcker N H, Guckian K M, Saghatelian A and Ghadiri M R 2008 Small 4427

18. (a) Pischel U 2010 Angew. Chem. Int. Ed. 49 1356; (b) de Ruiter G, Motiei L, Choudhury J, Oded N and Van der Boom M E 2010 Angew. Chem. Int. Ed. 49 4780; (c) Amelia M, Baroncini M and Credi A 2008 Angew. Chem. Int. Ed. 476240

19. AndrKasson J, Straight S D, Bandyopadhyay S, Mitchell R H, Moore T A, Moore A L and Gust D 2007 Angew. Chem. Int. Ed. 46958

20. AndrKasson J, Straight S D, Bandyopadhyay S, Mitchell R H, Moore T A, Moore A L and Gust D 2007 J. Phys. Chem. C111 14274

21. Perez-Inestrosa E, Montenegro J M, Collado D and Suau R 2008 Chem. Commun. 1085

22. Drezet A, Koller D, Hohenau A, Leitner A, Aussenegg F R and Krenn J R 2007 Nano Lett. 71697

23. (a) Kaur N and Kumar S 2012 Dalton Trans. 41 5217;

(b) Kaur N and Kumar S 2011 Supramol. Chem. 23768

24. Kaur N and Kumar S 2008 Tetrahedron Lett. 495067 